(c) 2020

\title{
Agricultural use of dried lands of the humid zone of Ukraine in conditions of agricultural sector reform and climate change
}

\author{
Voropai H. \\ Institute of water problems and land reclamation of NAAS \\ 37 Vasylkivska Str., Kyiv, 03022, Ukraine \\ e-mail: voropaig@ukr.net \\ ORCID: 0000-0002-5004-0727
}

\begin{abstract}
The purpose. To establish the peculiarities of agricultural use of drained lands of the humid zone of Ukraine in the conditions of reforming the agricultural sector and modern climate change to justify measures restoring efficient functioning of drainage systems in the mode of active water regulation. Methods. System analysis, the generalization of knowledge and materials of scientific researches concerning features of modern agricultural use of drained lands. Results. It is determined that the structure of sown areas on drained lands is subject to both climate change and export market conditions. In agricultural production, there is a cultivation of monoculture: corn, sunflower, rape, soybeans, sown areas of which are concentrated mainly in the ForestSteppe zone and Polissia. The main crops of traditional specialization (flax, sugar beet, rye, oats, etc.) have ceased to be a priority, but due to the environmental friendliness of domestic products and the uniquely favorable ecological and geographical position of their cultivation have the potential to conquer domestic and world markets. The result of the reform of the agricultural sector is that the vast majority of drained land belongs to rural households and only a third of them to enterprises. The potential of drainage systems is used inefficiently, and their water regulation capacity is an unused resource for increasing yields and sustainable agricultural production. Conclusions. Under the new conditions of growing crops and, accordingly, the functional tasks of drainage systems, the development of land reclamation in the humid zone should be aimed at their reconstruction and modernization. It is necessary to take into account the peculiarities of agricultural use of drained lands and the current level of the water supply of reclaimed areas.
\end{abstract}

Key words: drained lands, drainage systems, climate change, agricultural production.

DOI: https://doi.org/10.31073/agrovisnyk202011-08

Drained lands of the humid zone of Ukraine are an important factor in sustainable agricultural production, the efficiency of which largely depends on the economic, environmental and social stability of the region [1].

The experience of advanced farms shows that the regulation of water-air regime of the soil by conducting scientifically sound drainage reclamation and the application of a set of necessary agronomic measures in growing crops contribute to a significant increase in agricultural productivity and high and stable yields [2].

Drainage systems are located mainly in the Polissya area of Ukraine on a total area of 3.2 million hectares. During the period from 1965 to 1990, 1671 drainage systems were built, of which: unilateral drainage systems $-50 \%$, combined $-27 \%$, circulating with accumulation of drainage water $-8 \%$, polder $-15 \%$.

At the same time, the territory of Ukraine with excessive and sufficient atmospheric moisture over the past 25 years has decreased by $10 \%$ and occupies only $22.5 \%$ or 7,6 million hectares of arable land. Modern climate change creates new conditions for growing crops and, accordingly, transforms the role of drainage systems [3]. Given the clear trend towards further growth of climate aridity in Ukraine, as well as the formation in the humid zone not only conditions of waterlogging of soils, but also the deficit of moisture during the growing season, the need to restore and expand water regulation in drained lands to minimize climate change. to increase the efficiency of agricultural production in the humid zone.

At the same time, due to climate change, namely the temperature regime towards warming, the zone of the northern Forest-Steppe and Polissya of Ukraine becomes favorable for growing a number of cereals and legumes (corn, soybeans, sunflowers and others), previously uncharacteristic of this region. However, the deterioration of natural moisture conditions necessitates the artificial improvement of moisture supply of crops grown [4].

Therefore, today the restoration of efficient use of drainage systems in the mode of active water regulation is becoming a determining condition for the implementation of intensive technologies for growing crops and ensuring the efficiency of agriculture in the humid zone.

Analysis of recent research and publications. $62 \%$ of the reclamation fund of mineral and $71 \%$ of peatswamp soils of the country are concentrated on the territory of the humid zone of Ukraine. In general, reclamation measures were carried out on most of the lands of the reclamation fund $(60,5 \%)$ [5]. Due to this, the land reclamation rate of this region is quite high and corresponds to the level of countries such as the United States (60\%), Germany (66\%), the Netherlands (81\%) [6]. 
Crops in the humid zone of Ukraine occupy about $66 \%$, hayfields and pastures $-32 \%$, perennials $-2 \%$ of the total sown area of drained land. The decrease in sown areas under forage crops is explained by a decrease in the need for fodder due to a sharp reduction in the number of cattle [1].

A characteristic feature of agricultural use of drained lands in modern conditions is excessive plowing of the territory (plowing rate is 50-70\%, except for Transcarpathian, Ivano-Frankivsk and Rivne regions) [7].

Conducting modern agriculture in the humid zone is characterized by both positive and negative changes. Negative changes are manifested in the fact that in the structure of sown areas only a small share belongs to fodder crops (13\%); the area under crops under sunflower, corn and rapeseed increased significantly and decreased under wheat, fruits and berries, long flax, and fodder crops. Positive changes relate to the reduction of agricultural land (by $13 \%$ compared to 1990, arable land - by $11 \%$ ) and the cultivation of new varieties and hybrids of crops, the increase in yield of which is observed in the humid zone [8].

The results of recent studies show that after the reform of the agricultural sector and the unbundling of land without taking into account the technological integrity of drained areas; due to the change in the specialization of the region's farms; lack of effective landowners and weakening of human resources in the field of land reclamation (especially at the level of farmers and land users); low level of water regulation capacity of drainage systems due to unsatisfactory technical condition of engineering infrastructure and imperfection of design and technological solutions; the impact of climate change on the provision of water resources to drained areas, the potential of drained lands is used inefficiently [1,9].

The aim of the research is to establish the features of agricultural use of drained lands of the humid zone of Ukraine in terms of reforming the agricultural sector and modern climate change to justify measures to restore the effective functioning of drainage systems in active water regulation.

Materials and methods of research. Research methods are based on a systematic analysis and generalization of knowledge and research materials on the features of agricultural use of drained lands of the humid zone of Ukraine in terms of agricultural sector reform and modern climate change.

Research results. Traditional crops grown in the area of drainage reclamation are winter wheat and rye, potatoes, corn for silage, flax, clover, lupine and others. Due to the sufficient amount of moisture and nitrogen contained in drained peat soils, high yields are obtained primarily for those crops in which the main type of product is vegetative mass (perennial grasses, cabbage, carrots, potatoes, corn for silage, fodder beets). At the same time, the productivity of grain crops (winter rye and wheat, barley, oats) on drained peat soils of Polissya is 1,2-1,5 times higher than on mineral ones [10].

At the same time, in the conditions of climate change, reforming of the agricultural sector and the impact on agricultural production of demand of foreign and domestic markets for certain types of agricultural products, there were significant changes in the structure of sown areas and shifting of cultivation areas.

Therefore, changes in the geography of crops in the period from 1990 to 2018 are manifested in the movement of the barley growing zone from north to south (the main crops today are concentrated in the southern and central regions). Sunflower crops have shifted from the central and southern regions to the western and northern regions (although sunflower was not grown at all in Volyn, Ivano-Frankivsk and Ternopil regions 28 years ago). The zone of corn crops for grain moved to the north, where the area under this crop increased almost 10 times. As a result, today the total area of corn crops for grain in Polissya is 2,5 times higher than in the steppe.

However, rapeseed crops have moved from the western and northern regions to the center and south and are now fairly evenly distributed among the regions, except for the northern, which accounts for 14,1\% [11]. In 2000 in the five Polissya oblasts (Volyn, Zhytomyr, Kyiv, Rivne, and Chernihiv oblasts) soybean acreage alone accounted for only 2,0 thousand hectares and 15 years later the total soybean area in these oblasts was 594 thousand hectares, in Kyiv increased more than 100 times [12].

The current trend of agricultural production in the humid zone is to reduce the sown area under winter and spring wheat and fruits and berries by 1,3 and 2,7 times, respectively. There is also a decrease in crops of flax, fodder sown grasses, sugar beets, legumes [8].

The total area of cereals and legumes in Ukraine has not changed much on average over the last five years compared to 1990, but the share of their production in natural and climatic zones has changed. Due to the increase in yield in Polissya and the Forest-Steppe, $65 \%$ of grain is grown, although the share of their crops in these regions is only $53 \%$ [13].

According to breeders, the traditional spring crops for Ukraine will soon be corn for grain and sunflower, and all other crops will be given the role of predecessors. Such actions are driven by both climate change and the demand for these crops, which is mainly formed in the export market [14].

Today, Ukraine already produces $32 \%$ of sunflower seeds in the world and is a world leader in the supply of sunflower oil [14]. According to the results of 2017, its profitability is not less than 60\% [15]. The steady tendency to global warming affects the expansion of industrial crops of sunflower in the north of Ukraine, on soils with a $\mathrm{pH}$ level of 6,0-6,3 (and even less) [16].

As for the cultivation of corn for grain, today, according to agronomists, in the steppe zone it is quite risky, and in the forest-steppe and Polissya this crop is becoming the main along with winter wheat [14].

Ukraine ranks seventh among world producers of rapeseed, providing 4\% of the world market for this crop. High profitability and demand from exporters and processors encourage farmers to expand rapeseed acreage. This is the first crop at the time of harvest, which is almost $100 \%$ exported abroad. The rapeseed 
trend is confirmed not only by the farmers themselves, but also by official statistics: over the last two years, the area under rapeseed in Ukraine has increased by $62 \%$, respectively: from 0,8 million hectares in 2017 to 1,3 million hectares in 2019, the leaders in yield are Volyn, Khmelnytsky, Ternopil, Rivne and Vinnytsia regions, where farmers harvest on average more than $3 \mathrm{t} /$ ha of rapeseed. The main buyer of Ukrainian rapeseed as a raw material, which is almost entirely used for the production of biodiesel, is traditionally Europe [17].

Regarding soybean cultivation, in comparison with 1990 in 2016 there is an increase in its crops by 20 times. This culture occupies a leading position due to high profitability of cultivation and stable demand of domestic and world agricultural markets. In addition, soybeans are a unique fodder, food, technical, medicinal crop and an excellent precursor for any crop, including winter wheat, canola, sugar beet [18].

In general since 1990 the sown area of sunflower has increased by 3,8; corn for grain $-3,7$; rapeseed $-11,6$, soybeans $-20,0$ times, their products today are the basis of exports (Table) [19]. At the same time from 42 to $83 \%$ of crops of these crops are located in the forest-steppe and Polissya [13].

Dynamics of increase of sown areas under the main agricultural crops in Ukraine [19]

\begin{tabular}{|c|c|c|c|c|c|}
\hline \multirow[b]{2}{*}{ Culture } & \multicolumn{4}{|c|}{ Year } & \multirow{2}{*}{$\begin{array}{c}\text { The } \\
\text { period from } \\
1990 \text { to } 2018 \\
\text { years, } \%\end{array}$} \\
\hline & 1990 & 2000 & 2015 & 2018 & \\
\hline Sunflower & 1626,3 & 2841,6 & 5166,2 & 6117 & 376 \\
\hline Corn for grain & 1223,1 & 1278,8 & 4083,5 & 4580 & 374 \\
\hline Sugar beets (factory) & 1605,4 & 747 & 237 & 276 & -17 \\
\hline Rapeseed & 89,6 & 156,7 & 671,1 & 1042 & 1163 \\
\hline Soy & 87,8 & 60,6 & 2135,6 & 1716 & 1954 \\
\hline
\end{tabular}

The increase in the absolute value of rapeseed and soybean acreage was accordingly reflected in the share of these crops in the total sown area of industrial crops. Thus, the dynamics of the share of soybeans in the total sown area of industrial crops since 1990 increased from $2,4 \%$ to $21,1 \%$ in 2016 , rapeseed - from 2,4 to $21,4 \%$. The opposite trend is observed in the dynamics of the share in the total sown area of industrial crops of sugar beets and flax: if in 1990 the share of these crops was 42,8 and 4,6\%, respectively, in $2016-3,3$ and less than $0,5 \%[20]$.

Flax was a traditional culture not only of Polissya districts (Chernihiv, Zhytomyr, Sumy, Rivne and Volyn regions, but also partly of Lviv, Ivano-Frankivsk and Chernivtsi regions). Flax growing in the recent past (flax occupied no more than $10 \%$ of sown area), provided more than half of all cash receipts from crop production, which contributed to the socio-economic development of farms in the Polissya region. For many decades Ukraine was one of the world's largest producers and exporters of flax fiber and other products of the linen industry [21]. This was largely due to proper government support for the industry and, as a result, the profitability of long flax seed production was $144-150 \%$ [22].

However since 1995 there has been a rapid collapse of the flax industry. Production of long flax decreased to the level of lower domestic needs. From a highly profitable flax industry has become unprofitable, which has led to a loss of interest of farmers in growing long flax. Currently flax growing is so declining that we have arable land across the country a little more than 1 thousand hectares. Today $70 \%$ of the flax market in Europe is occupied by France and partly by Belgium and the Netherlands [22].

For producers today, flax has only nutritional value, but even here its profitability loses compared to most other crops. Therefore, flax remains an exclusively niche crop. However, according to Ukrainian flax seed exporters (Public Association of the Association of Flax and Hemp Development of Ukraine), the revival of the industry should take place through the sale of seeds, as they calculate that exporting flax seeds of high food quality is twice as profitable as producing oil. And to realize this vision, it is necessary to create a favorable climate for foreign investment in technology [21].

According to scientists, the cultivation of oil flax is also promising in Ukraine, which due to the naturalness of domestic products has a chance to conquer new European markets. And although the main problem of the industry is the lack of plants for its processing, because all oil companies are engaged in processing sunflower, rapeseed and soybeans, but a significant reason for the popularity of oil flax is a wide range of applications [23].

In Ukraine sugar beets have traditionally been the highest priority industrial crop. Beet crops in the 80s amounted to 1,7 million hectares, now $-313,6$ thousand hectares. By the 1990, Ukraine accounted for up to $15 \%$ of the world's sugar beet crops, up to $14 \%$ of their gross harvest and $10 \%$ of sugar production. Today Ukraine is among the top five in the world in the production of sugar beets per capita.

Despite the fact that sugar beet gives almost the highest profit among all traditional crops, but this prospect does not tempt farmers to start growing sugar beets, because this crop is also one of the most difficult to grow. Currently the beet industry in Ukraine is in crisis, and the main problems of growing sugar beets are the neglect of crop rotations, the use of outdated equipment and unwillingness to implement bioadaptive technologies [24].

In 2020-2021, given the reduction of sown areas and weather conditions, which already significantly affect the yield of sugar beets, as it is known that this year's dust storms damaged some crops in Ternopil, 
Kharkiv and Kirovohrad regions, the central regions suffer from pests, sugar production is projected to be $15 \%$ lower than in previous years [25].

In the period 2004-2013, there was also a significant reduction in the production of such traditional crops as rye: if in 2004 206,4 thousand tons were produced, in 2013 - only 63,8 thousand tons of grain. Accordingly the share of rye in the total production of cereals and legumes in 2004 was $16,5 \%$, and in $2013-2,8 \%$. Today the area of crops of this important crop is 148 thousand hectares. That is, one of the main cultures of the traditional specialization of the humid zone has ceased to be one of the priorities of agricultural production [11, 26].

Today Ukraine ranks sixth in the world in terms of rye grain production after Russia, Germany, Poland, Belarus and even China, which until recently did not sow this crop at all. According to scientists, our country has a uniquely favorable ecological and geographical position for the production of the most competitive in Europe and the world and the highest quality rye grain. In addition, the results of research conducted by the Laboratory of Breeding and Genetics of Winter Rye of the Yuryev Institute of Plant Breeding show that rye is one of the most universal and unpretentious cereals, and the profitability of growing its hybrids reaches 900 $1200 \%$ [27]. According to agricultural market experts, given the realities of growing rye, not enough attention is paid by agribusiness, as the external conjuncture of the world grain market plays a role, where rye is not in such demand as other cereals [26].

Over the past eight years in Ukraine there has also been a reduction in sown areas of oats (from 442,3 to 241,3 thousand hectares). The main areas of oats are concentrated in Polissya $(56,1 \%)$ and forest-steppe $(28,2 \%)$, but here too there is a gradual reduction of areas under its crops: from 236,7 to 139,7 thousand hectares in Polissya, from 135,6 up to 53,9 thousand hectares in the forest-steppe. The average grain yield of oats is in the range from 1,42 to $2,17 \mathrm{t} / \mathrm{ha}$ [28]. It is believed that the main reason for this trend is structural changes in animal husbandry, a decrease in the number of horses for which oats are the main food; the second reason is relatively low yields; the third is lower energy nutrition than other forage crops. However, according to scientists, this crop is still characterized by a fairly high grain yield potential, because when using elements of modern technologies for its cultivation, grain harvest can reach 5,0-5,5 t/ha [29].

Evidence of changes in the structure of agricultural production is also the dynamics of sown areas of perennial and annual grasses. In 2016, compared to 1990, the sown area of perennial and annual grasses in Ukraine as a whole decreased by 4 and 7 times, respectively, which is primarily due to a reduction in the livestock industry [20].

The current trend in Ukraine is the growing interest in technical hemp, and this is primarily due to the growing demand for their products. Today there are more than 25 thousand products that can be produced from hemp, and this range is expanding every year, and the growing demand for their raw materials encourages farmers to increase crops of this crop. For example, in the last decade, the total area of hemp fields in the EU has quadrupled to 43,000 hectares, and China, the world leader in the industry, intends to increase hemp crops to 670,000 hectares, partially replacing cotton. In Ukraine, hemp is currently grown on 4.5 thousand hectares. Recently, the domestic company Hemptechno LLC has created equipment for primary processing of hemp trusts, and in the Cherkasy region, in Zolotonosha, it is planned to build a plant for processing technical hemp, which will accept raw materials from farms. Thus, there is a basis for the beginning of positive changes in the direction of obtaining natural, environmentally friendly products from this culture [30].

Today, scientists of Institute of Water Problems and Land Reclamation NAAS are also conducting research on the scientific support of growing promising and profitable crops, which in modern conditions with open world markets, modern land users are increasingly beginning to grow. These are non-traditional crops for the drained lands of Polissya: berries, fruits, medicinal, rare fodder and others. Thus, the cultivation of medicinal plants on drained lands is a new trend that requires justification of its feasibility and study of the economic component. At present, the prospects of growing medicinal plants on drained lands are substantiated, provided that the optimal water-air regime of drained soils is provided and in combination with a rational fertilization system.

For scientifically substantiated agricultural production on drained lands, research is also conducted on technologies for growing highly productive fodder crops (paise, amaranth, fodder beans). Their species for growing on drained lands are substantiated according to the criteria: economic efficiency, adaptability, energy and nutritional value, range of uses (fodder, food, medicine). Technological parameters of their cultivation on different types of drained soils have also been developed [31].

Thus, on the drained lands there was actually a change in the specialization of agricultural production, which changed the structure of sown areas of crops grown. Traditional crops grown in the area of drainage reclamation (rye, oats, corn for silage, flax, sugar beets, etc.) have been replaced by economically attractive crops, the cultivation of which is subject to the market situation of agricultural products.

Due to the change in the specialization of agricultural production, another problem is the oversaturation of the crop structure with intensive crops and complete disregard for crop rotations as an important measure to preserve soil quality and agricultural culture [19].

According to scientists, since modern agricultural production is accompanied by non-compliance with crop rotations and inadequate scientific substantiation of agrotechnical and hydro-ameliorative measures, the effective use of drained lands requires the development of arable land structure, including crop rotations, which take into account the specialization of existing agricultural production. 
Given the fact that in modern economic conditions the determining factors in the formation of crop rotations is market demand for certain products with appropriate quality indicators and economic feasibility of their cultivation, then, according to farmers, it requires the introduction of multi-rotation (including increased dynamism) crop rotations, which allow the producer to respond quickly to changes in the market without violating the requirements for crop rotation. Mobile short-rotation crop rotations require the selection of the best predecessors for crops, taking into account their economic importance and biological characteristics, natural and ecological conditions and cultivation technologies [33].

According to the results of a survey (conducted by AgroPortal.ua) on the conduct of modern agricultural production and changes in the structure of crops, it was found that $18 \%$ of farmers intend to radically change the structure of crops; $18 \%$ are not going to change anything; $13 \%$ of farmers are going to change not the structure of crops, but the approach to agriculture; $5 \%$ plan to engage in niche crops, $4 \%$ said that the main thing for them will be the pricing indicator, another $4 \%$ are not going to introduce new crops in crop rotation [34].

To substantiate the system of modern agricultural production on reclaimed lands scientists of Institute of Water Problems and Land Reclamation NAAS assessed the agro-resource potential of agricultural areas and the formation of competitive agroecosystems on drained lands, proposed promising options for intersectoral optimization with the formation of adapted to the conditions of regions [35].

Along with this, an important factor influencing the conduct of agricultural production on drained lands is the reform of the agricultural sector. To date, more than 950 thousand land users of drained lands have been formed: state agricultural collective enterprises ( $3 \%$ of the total area of drained lands); non-state agricultural associations (27\%); peasant (farmer) farms (4\%); allotments of citizens provided to them for use (49\%); jointstock companies and farms of other forms (17\%).

The average size of the land share (share) is from 2,4 to 4,8 hectares. The size of land plots in most land users does not allow for profitable and highly profitable production of marketable products. $75-80 \%$ of shares on drained lands are leased by landowners to agricultural formations of various forms of ownership [1,2].

According to the study, less than $5 \%$ of crops of cereals and oilseeds are grown by individual farmers, as evidenced by the results of satellite monitoring conducted by the World Bank [36].

Thus, agricultural production on drained lands gradually moved to the sector of private farms. If in 1990 $98,9 \%$ of drained agricultural lands were used by agricultural enterprises, in $2016-33,5 \%$. In general, only a third of drained agricultural land is used by agricultural enterprises, and the vast majority belongs to rural households [37].

An important aspect of modern agricultural development is the size of production. In many crops there is an increase in the concentration of agricultural production, when a small share of enterprises actually has a significant share in the formation of supply in the market. In addition, there is a certain relationship between the level of concentration of production and its efficiency, as modern wholesale production has more opportunities and access to financial resources. On the one hand, this indicates a fairly high efficiency of innovative agricultural technologies, and on the other - a significant and underutilized reserves in other farms [38].

Characteristic of modern agricultural production on drained lands is also the inefficient use of the existing potential of drainage systems, and their water-regulating capacity - an unused resource to increase yields and sustainable agricultural production in climate change.

Existing drainage systems are structurally and technologically designed for operation as a whole, and reclaimed land with their help - for use in large collective or state farms. The reform of the agricultural sector, which was carried out without taking into account the technological conditions of operation of drainage systems, led to the violation of established technologies of land use and management of drainage systems. Due to the discrepancy between the technological integrity embedded in the existing systems at the design stage and the modern infrastructure of users of reclaimed lands, today the water regulation processes on drained lands are virtually unmanageable.

Given the formation of new conditions for growing crops and, accordingly, the functional tasks of drainage systems, the development of land reclamation in the humid zone is aimed at their reconstruction and modernization of systems [4]. At the same time, along with the main criteria such as technical condition of engineering infrastructure elements, changes in ecological and reclamation, hydrological and soil conditions of their operation, which determine the inability of the system to provide operational management of water-air regime of soils, drainage systems should be taken into account. as well as changes in the use of drained land. This will allow at the request of a specific land user to develop and implement a set of measures for technical re-equipment and reconstruction of a specific drainage system, to use advanced resource-saving and environmentally sound water management technologies on drained lands.

To implement such tasks, modern requirements for the construction of drainage systems must take into account changes related to the reform of the agricultural sector, agronomic and environmental requirements of land users of drained lands, modern climate change. These requirements are determined on the basis of analysis of design materials of drainage systems located in different natural and climatic conditions of the humid zone, and on the results of field research on drainage systems in Chernihiv, Rivne, Volyn and Zakarpattia regions, and include:

- the need to take into account the peculiarities of modern land management and change the specialization of agricultural production in the humid zone; 
- the need to ensure the operational management of technological processes of water regulation and maintaining the optimal water regime of the active layer of soil with the use of reliable and easy to operate technical means;

- expediency of using effective technological schemes of water regulation, which are used on drainage and humidification systems, as well as elements of engineering infrastructure on the internal network, which are in satisfactory technical condition, which will restore the functioning of systems by technical re-equipment of the internal network with insignificant costs in the first years of their implementation;

- providing increased efficiency of agricultural production on drained lands by land users of various forms of ownership and management.

The developed designs of block-modular water-circulating drainage-humidification systems, drainagehumidification systems with a cascade of accumulating reservoirs, water-circular drainage-humidification systems of polder type can satisfy such requirements [39-41].

Since at the present stage of reforming the country's water management system the drainage system is divided (unsoldered) and does not play the role of an integral engineering infrastructure, it is also important to use local parts (modules) of the system, which, subject to their structural and technological modernization, -air regime of the soil, which can become a promising area of land reclamation of the humid zone of Ukraine.

In the conditions of modern climate changes, which are accompanied by instability of water supply of reclaimed territories, for realization of effective water regulation at cultivation of agricultural crops increase of water supply of drainage systems is necessary. The creation of guaranteed volumes of water to regulate the water regime on drained lands is based on the use of water accumulation capacity of reclamation systems, which can be achieved by: using the accumulation capacity of the soils of the aeration zone; use of the accumulative capacity of the network of open channels; creation of a system (cascade) of bulk reservoirs for water accumulation with its subsequent use in dry periods to regulate the water regime of drained soils, as well as the use of natural reservoirs as sources of water supply.

Structural and technological solutions have also been developed, the implementation of which makes it possible to ensure prompt and effective management of technological processes of water regulation and create guaranteed volumes of water for moistening the active layer of soil in dry periods (Fig.).

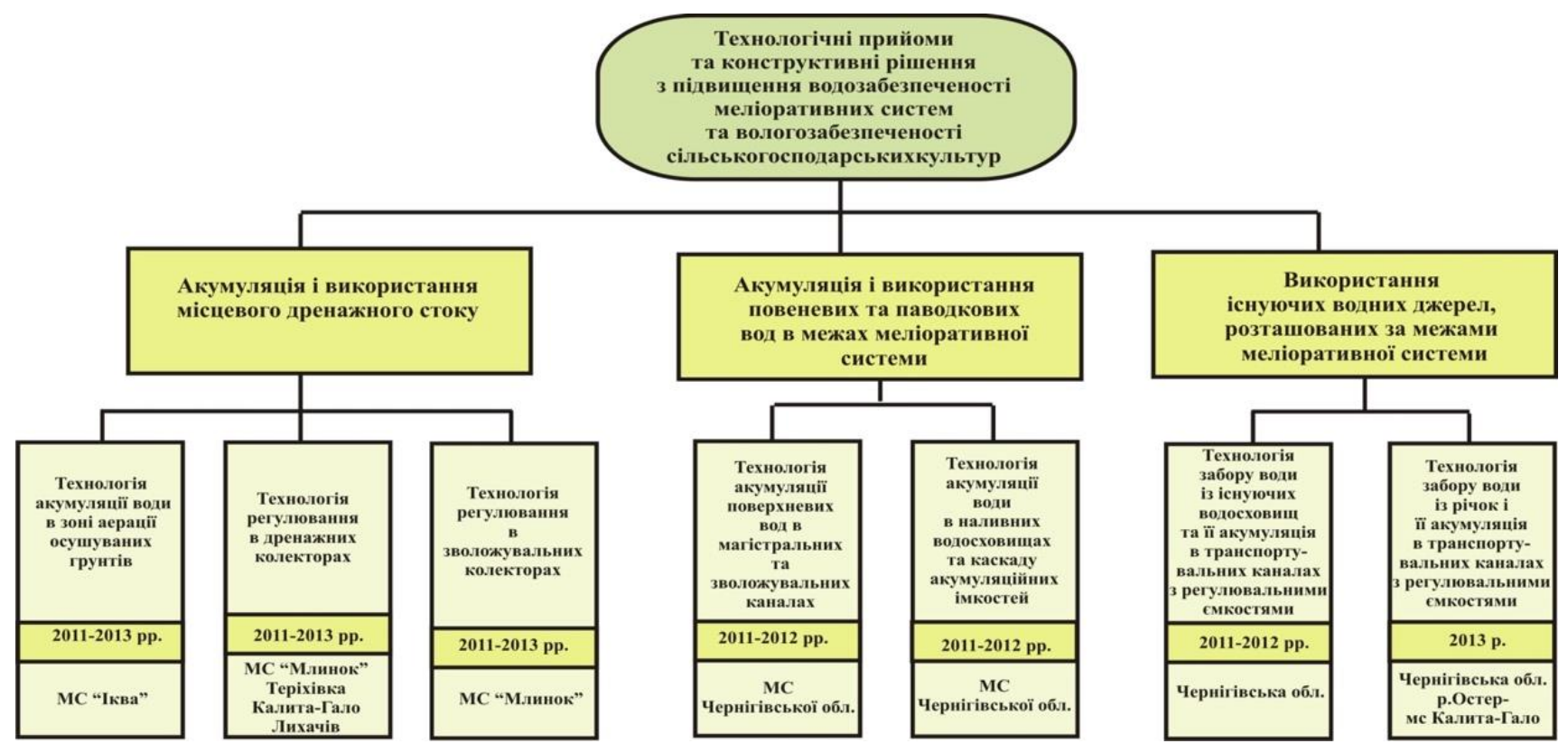

The structure of the main directions of increasing the water supply of reclamation systems

The implementation of the proposed solutions for the accumulation of water and drainage runoff tested on drainage systems in Chernihiv, Rivne (2011-2013) and Sumy (2014-2015) regions indicates the possibility of accumulating sufficient volumes of water for wetting and achieving increasing the required water content of reclaimed areas [42, 43].

\section{Conclusions}

According to the results of the analysis of the peculiarities of agricultural use of drained lands of the humid zone, it is established that the current structure of sown areas is subject to both climate change and market conditions, which dictates the cultivation of economically attractive crops. In general monoculture (grain corn, sunflower, rapeseed, soybean) is grown in agricultural production.

The main crops of traditional specialization (flax, sugar beets, rye, oats and others) of the humid zone are no longer a priority in modern agricultural production, but due to the naturalness of domestic products and 
uniquely advantageous ecological and geographical position of their cultivation have the potential to win domestic and world markets. today they remain mostly niche crops.

Due to the reform of the agricultural sector, only a third of drained land belongs to enterprises, and the vast majority - to rural households, with about $80 \%$ of shares in drained land leased by landowners to agricultural formations of various forms of ownership. The current trend is an increase in the concentration of agricultural production in the cultivation of major crops, when a small share of enterprises has a significant share in the formation of supply in the market. At the same time, there is a relationship between the level of concentration of production and its efficiency.

It is determined that due to the formation of new conditions for growing crops and, accordingly, the functional tasks of drainage systems, the development of land reclamation in the humid zone should be aimed at their reconstruction and modernization, which should take into account the peculiarities of agricultural use of drained lands water supply of reclaimed territories.

\section{References}

1. Kontseptsiia efektyvnoho vykorystannia osushuvanykh zemel humidnoi zony (naukovi zasady) [The concept of effective use of drained lands of the humid zone (scientific principles)]. (2013). Kyiv. [in Ukrainian].

2. Melioratsiia hruntiv (systematyka, perspektyvy, innovatsii). [Land reclamation (systematics, prospects, innovations)] (2015). Collective monograph. Kherson: Hrin D.S. [in Ukrainian].

3. Romashchenko, M.I. et al. (2019). Vplyv klimatychnykh zmin na volohozabezpechennia terytorii Ukrainy ta vyrobnytstvo silskohospodarskoi produktsii [Influence of climatic changes on moisture supply of the territory of Ukraine and production of agricultural products]. (pp. 179 - 180). "Water for All": dedicated to World Water Day: International. scientific-practical Conference: thesis add. Kyiv. [in Ukrainian].

4. Stratehiia zroshennia ta drenazhu v Ukraini na period do 2030 roku. (2019). № 688-r. [Irrigation and drainage strategy in Ukraine until 2030]. Approved by the Cabinet of Ministers of Ukraine. [in Ukrainian].

5. Kozhushko, L.F., \& Velesyk, T.A. (2015). Formuvannia rynku osushenykh zemel silskohospodarskoho pryznachennia [Formation of the market of drained lands of agricultural purpose]. Monograph. Rivne: NUVHP. [in Ukrainian].

6. Suchasnyi stan, osnovni problemy vodnykh melioratsii ta shliakhy yikh vyrishennia [The current state, the main problems of water reclamation and ways to solve them]. (2001). Kyiv: Ahrarna nauka. [in Ukrainian].

7. Lymar, V. V., \& Baydala, V. V. (2019). Pryrodnyi potentsial rozvytku biooriientovanoi ekonomiky v Ukraini [Natural potential of bio-oriented economy in Ukraine]. Businessinform, 9, $136-143$. [in Ukrainian].

8. Datsko, L.V. (2016). Suchasne silskohospodarske vykorystannia zemel humidnoi zony Ukrainy [Modern agricultural use of lands of the humid zone of Ukraine] Melioration and water management, 103, 41-47. [in Ukrainian].

9. Voropai, H.V., Yatsyk, M.V., \& Mozol, N.V. (2019). Suchasnyi stan ta perspektyvy rozvytku osushuvalnykh melioratsii v umovakh zmin klimatu [Current state and prospects of development of drainage reclamation in the conditions of climate change]. Reclamation and water management, 2, 31-39. [in Ukrainian].

10. Sakal, O. (2016). Priorytetni napriamy vykorystannia osushenykh zemel v Ukraini [Priority areas of drained lands in Ukraine]. Economist, 5, $41-45$. [in Ukrainian].

11. Heohrafiia, vrozhainist, ploshchi: yak zminylos vyroshchuvannia topovykh kultur za roky Nezalezhnosti? Agravery (ahrarne informatsiine ahentstvo) [Geography, yield, area: how has the cultivation of top crops changed during the years of Independence? Agravery (Agrarian News Agency)]. URL: https://agravery.com/uk/posts/show/geografia-vrozajnist-plosi-ak-zminilos-virosuvanna-topovih-kultur-zaroki-nezaleznosti [in Ukrainian].

12. Rozrobka kontseptsii natsionalnoi polityky adaptatsii silskoho hospodarstva Ukrainy do zminy klimatu. Zakliuchnyi zvit zavdannia Sluzhby ekspertnoi pidtrymky Clima East CEEF2016-083-UA, proekt [Development of the concept of the national policy of adaptation of agriculture of Ukraine to climate change. Final report of the task of the Clima East Expert Support Service CEEF2016-083-UA, project]. 2017. [in Ukrainian].

13. Romashchenko, M.I. et al. (2020). Vplyv suchasnykh klimatychnykh zmin na vodni resursy ta silskohospodarske vyrobnytstvo [The impact of modern climate change on water resources and agricultural production]. Land reclamation and water management, 1, 5-22. [in Ukrainian].

14. Draiveramy ukrainskoho roslynnytstva stanut kukurudza ta soniashnyk [Corn and sunflower will become drivers of Ukrainian crop production]. URL: https://landlord.ua/news/drayverami-ukrayinskogoroslinnitstva-stanut-kukurudza-ta-sonyashnik/ [in Ukrainian].

15. Soniashnyk rukhaietsia na pivnich Ukrainy. Ynfoyndustryia. ITs UAK za materialamy AgroDay [Sunflower moves to the north of Ukraine. Infoindustry. IC UAC according to AgroDay]. URL: https://infoindustria.com.ua/sonyashnik-ruhayetsya-na-pivnich-ukrayini/ [in Ukrainian].

16. Klimatychni zminy vplyvaiut na rozshyrennia posiviv soniashnyku v Ukraini. ProAhro Hrup [ ]. URL: http://www.proagro.com.ua/news/ukr/26732.html

17. Rynok ozymoho ripaku: svitovi tendentsii [Climate change is affecting the expansion of sunflower crops in Ukraine. ProAgro Group]. URL: https://www.syngenta.ua/news/ripak-ozimiy/rinok-ozimogo-ripaku-svitovitendenciyi [in Ukrainian]. 
18. Vyroshchuvannia soi za klasychnoiu tekhnolohiieiu [Growing soybeans by classical technology]. URL: https://kurkul.com/spetsproekty/636-viroschuvannya-soyi-za-klasichnoyu-tehnologiyeyu [in Ukrainian].

19. Hladii, M.V., \& Luzan, Yu.la. (2020). Zemelna reforma: suchasni problemy i shliakhy yikh vyrishennia [Land reform: modern problems and ways to solve them]. Economics of AIC, 2, 6-19. [in Ukrainian].

20. Sunduk, A.M., Holian, V.A., Androshchuk, I.I., \& Savchuk, V.V. (2018). Ahrarne pryrodokorystuvannia v Ukraini: instytutsionalne pidgruntia, osnovni tendentsii ta finansovo- ekonomichni mekhanizmy ratsionalizatsii [Agrarian nature management in Ukraine: institutional basis, main tendencies and financial and economic mechanisms of rationalization]. Economy and State, 9, 19-29. [in Ukrainian].

21. Koly povernemo lonarsku slavu? TOV Zemlia i volia [When will we return the glory of flax? LLC "Land and Freedom"]. URL: http://zemlyaivolya.net/news/koli_povernemo_lonarsku_slavu.html [in Ukrainian].

22. Prohrama rozvytku ahropromyslovoho kompleksu Zhytomyrskoi oblasti na 2016-2020 roky [Program of development of agro-industrial complex of Zhytomyr region for 2016-2020]. URL: http://agroprom.zt.gov.ua/images/pdf/prog_1.pdf [in Ukrainian].

23. Popyt na lon vidchutno zrostaie [Demand for flax is growing significantly]. URL: http://agrobusiness.com.ua/agro/idei-trendy/item/13583-popyt-na-lon-vidchutno-zrostaie.html [in Ukrainian].

24. Ilkiv, L.A. (2018). Suchasnyi stan ta efektyvnist vyrobnytstva tsukrovykh buriakiv [Current state and efficiency of sugar beet production]. Young scientist, 11 (63), 1124-1127. [in Ukrainian].

25. Vyrobnytstvo tsukru $v$ Ukraini zmenshuietsia (2020). [Sugar production in Ukraine is declining]. Agribusiness Today, 11 (426), 8. [in Ukrainian].

26. Zhyto-zhyto, yak bez tebe zhyty? [Rye-rye, how to live without you?]. Agrarian week. Ukraine. URL: https://a7d.com.ua/plants/8569-zhito-zhito-yak-bez-tebe-zhiti.html [in Ukrainian].

27. Rentabelnist vyroshchuvannia zhyta stanovyt $900-1200 \%$ [The profitability of growing rye is $900-1200 \%$ ]. URL: https://superagronom.com/articles/15-dmitro-yegorov-rentabelnist-viroschuvannya-jita-stanovit-9001200 [in Ukrainian].

28. Cherchel, V.lu., Fedorenko, E.M., Aldoshyn, A.V., Solodushko, V.P., \& Liashenko, N.O. (2014). Oves stan ta efektyvnist vyrobnytstva, novi sorty i mozhlyvosti [Lyashenko NO Oats - condition and efficiency of production, new varieties and opportunities]. Breeding and seed production, 106, 183-190. [in Ukrainian].

29. Maister, A.A., Yevtushok, I.M., Maister, O.A., \& Salii, A.P. (2005). Elementy intensyvnoi tekhnolohii vyroshchuv annia vivsa v zoni polissia [Master AA, Yevtushok IM, Master OA, Saliy AP Elements of intensive technology of oat growing in the forest zone]. Visnyk of DAU, 1, 75-81. [in Ukrainian].

30. V Ukraini zapratsiuie promyslova liniia z pererobky konopel. Agronews (holovni ahrarni novyny) [An industrial hemp processing line will start operating in Ukraine. Agronews (main agricultural news)]. URL: https://agronews.ua/news/blyzko-8-mln-ha-tinovoho-obrobitku-zemli-v-ukraini-zdiysniuie-orhanizovanyybiznes/ [in Ukrainian].

31. latsyk, M.V., Voropai, H.V., \& Kika, S.M. (2019). Obgruntuvannia rezhymiv vodorehuliuvannia pry vyroshchuvanni vysokoproduktyvnykh kormovykh kultur na osushuvanykh zemliakh [Substantiation of water regulation regimes in the cultivation of highly productive fodder crops on drained lands]. Bulletin of Agricultural Science, 5, 60-67. [in Ukrainian].

32. Sliusar, I.T., Hera, O.M., Solianyk, O.P., \& Serbeniuk, V.O. (2015). Pryrodookhoronne vykorystannia osushuvanykh zemel humidnoi zony [Environmental use of drained lands of the humid zone], Agriculture, 2, 51-55. [in Ukrainian].

33. Dankevych, A.le., \& Bovsunovskyi, A.M. (2011). Osoblyvosti formuvannia struktury posiviv ta struktury sivozmin v umovakh Zhytomyrskoi oblasti [Features of formation of structure of crops and structure of crop rotations in the conditions of Zhytomyr region]. Agrosvit, 13-14. URL: http://www.agrosvit.info/pdf/1314_2011/7.pdf [in Ukrainian].

34. Zmina klimatu chy koniunktura rynkiv: shcho zmushuie ahrariiv zminiuvaty strukturu sivozminy [Climate change or market conditions: forcing farmers to change the structure of crop rotation]. URL: https://www.Inz.com.ua/news/zmina-klimatu-ci-konunktura-rinkiv-so-zmusue-agrariiv-zminuvati-strukturusivozmini [in Ukrainian].

35. Romashchenka, M.I., \& Tarariko, Yu.O. (Ed.). (2017). Meliorovani ahroekosystemy. Otsinka ta ratsionalne vykorystannia ahroresursnoho potentsialu Ukrainy (zony zroshennia i osushennia) [Reclaimed agroecosystems. Assessment and rational use of agro-resource potential of Ukraine (irrigation and drainage zones)]. Nizhyn: PP Lysenko M.M. [in Ukrainian].

36. Blyzko $8 \mathrm{mln}$. ha tinovoho obrobitku zemli v Ukraini zdiisniuie orhanizovanyi biznes. Agronews (holovni ahrarni novyny) [About 8 million hectares of shady tillage in Ukraine are organized. Agronews (main agricultural news)]. URL: https://agronews.ua/news/blyzko-8-mln-ha-tinovoho-obrobitku-zemli-v-ukrainizdiysniuie-orhanizovanyy-biznes/ [in Ukrainian].

37. Kuzmenko, S., \& Bieliak, M. (2015). Finansovi aspekty stanovlennia ahrarnoho pidpryiemnytstva $v$ zoni osushuvalnykh melioratsiy [Financial aspects of agricultural entrepreneurship in the area of drainage reclamation]. Economist, 10, 36-38.

38. Kernasiuk, Yu.V. (2020). Suchasnyi ahrobiznes: chy vplyvaie rozmir na efektyvnist [Modern agribusiness: does size affect efficiency]. Agribusiness Today, 11 (426), 14-17. [in Ukrainian].

39. Doslidyty zakonomirnosti transformatsii meliorovanykh ahrolandshaftiv ta rozrobyty naukovi osnovy intehrovanoho upravlinnia vodno-zemelnymy resursamy na meliorovanykh terytoriiakh zony 
nadlyshkovoho zvolozhennia [Investigate the patterns of transformation of reclaimed agricultural landscapes and develop the scientific basis for integrated management of water and land resources in reclaimed areas of excess moisture]. Zvit pro NDR za zavdanniam 03.03.01-035, № derzh. reiestr. $0107 \mathrm{U}$ 005092, K., - 2009, - v trokh knyhakh: kn. $1-51$ s.; kn. $2-76$ s.; kn. $3-89$ s. Fondy IHiM. [in Ukrainian]. 40. Chalyi, B. I., \& Drobot, O. V. (2011). Tekhnolohiia rehuliuvannia vodnoho rezhymu osushuvanykh zemel z vykorystanniam drenazhnoho stoku [Technology of regulation of water regime of drained lands with the use of drainage runoff]. Land reclamation and water management, 99, 91 - 97. [in Ukrainian].

41. Tyshenko, O.I., \& Nahaliuk, S.I. (2012). Zvolozhennia osushuvanykh zemel Livoberezhnoho Polissia Ukrainy [Humidification of drained lands of the Left Bank Polissya of Ukraine]. Water Management of Ukraine, 2, 21 - 25. [in Ukrainian].

42. latsyk, M.V., Voropai, H.V., Topolnik, T.I., \& Shushkevych, Yu.A. (2015). Metodolohichni osnovy pidvyshchennia vodozabezpechenosti melioratyvnykh system shliakhom stvorennia akumuliuiuchykh yemkostei [Methodological bases of increase of water supply of reclamation systems by creation of accumulating capacities]. Reclamation and water management, 102, 54 - 58. [in Ukrainian].

43. latsyk, M.V., Voropai, H.V., \& Moleshcha, N.B. (2016). Pidvyshchennia vodozabezpechenosti melioratyvnykh system humidnoi zony [Improving water supply of reclamation systems of the humid zone]. Reclamation and water management, 103, 63 - 68. [in Ukrainian]. 